
AUTOMOBILE DEALERSHIPS

\author{
Juhani Iivari, \\ Department of Information Processing Science, University of Oulu, \\ Oulu, P.O. Box 3000, Fin-90014, Finland \\ E-Mail: Juhani.Iivari@oulu.fi \\ Phone: +358-8-553-1922, Fax: 358-8-553-1890 \\ Marius Janson \\ Department of Information Systems, University of Missouri-St. Louis \\ St. Louis, MO 63121, USA \\ E-Mail: janson@umsl.edu \\ Phone: 314-516-5846, Fax: 314-516-6827
}




\title{
ANALYSIS OF ELECTRONIC COMMERCE ADOPTER CATEGORIES IN RETAILING: THE CASE OF AUTOMOBILE DEALERSHIPS
}

\begin{abstract}
Based on a qualitative analysis of semi-structured interviews of seven automobile dealerships in the City of Oulu, Finland, we uncovered four themes - strategic understanding of electronic commerce, technological understanding of electronic commerce, maturity of the website supporting electronic commerce, and electronic commerce developmental strategy - which allowed to make sense in a succinct way of the similarities and differences among seven automobile dealerships. Locating the seven dealerships on these four themes (dimensions) yielded quite consistent patterns, and led us to identify adopter categories of electronic commerce. We suggest three major adopter categories: "procrastinators," "followers," and "visionaries." "Followers" are divided further into "opportunists," "waverers," and "striders." The analysis of the histories of websites also showed that the existence of a website as such and its operational use are not sufficient to trigger effective learning about electronic commerce. We suggest that the learning at the levels of strategic and technological understanding of electronic commerce are joint outcomes of electronic commerce developmental strategy and the website maturity rather than either of them separately. The interviews also showed that the dealers with higher strategic and technological understanding tended to have a more active electronic commerce developmental strategy and more mature websites. This led us to conjecture that the developmental strategy and the website maturity are influenced by both strategic and technological understanding.
\end{abstract}

Key words: Electronic commerce, retailing, automotive industry, dealerships, adoption, Finland

\section{INTRODUCTION}

Electronic commerce (eCommerce) is strategically significant for many businesses [1]. It has been predicted that eCommerce will radically influence the value chain and business processes of industries and may lead to disintermediation and reintermediation [2-5]. However, much of the discussion on intermediation, disintermediation and reintermediation has been speculative [6]. Because of the newness of eCommerce there is little definitive empirical evidence about its potential effects on industry structures. On the other hand, one can claim that the popular and academic presses have given disproportional attention to eCommerce as a technology for creating new businesses. Perhaps, as a result of the recent demise of many dot.com companies, attention is shifting to eCommerce applications in existing businesses. For example, a New York Timesarticle (Wednesday, December 13, 2000, pp. E2, E11, E16) described the failure of several well-known eCommerce startups and emphasized that organizations most likely to successfully use eCommerce were firms that existed before the advent of eCommerce.

If the New York Times assertion is correct then it is important to study what existing companies do when they introduce eCommerce. In particular the position of retailers in the supply chain is at stake because they may be subject to disintermediation [7]. It goes without saying that a likelihood of disintermediation creates much uncertainty among retailers. Also businesses that will not be eliminated from an altered supply chain must evaluate the potential benefits, costs and risks of eCommerce participation, because the status quo is an unlikely option. Hence, this paper centers on the adoption of eCommerce as a strategic innovation in retailing with a particular emphasis on the factors that enable adoption. 
For reasons to be explained in Section 2 we selected the automotive industry and in particular the adoption of eCommerce by auto dealerships as an empirical field of study. One can expect that decisions about adoption or rejection of eCommerce in auto dealerships are of strategic importance to the adopting units. Moreover, we anticipate that auto dealers experience considerable risk and uncertainty related to the industry's potential structures arising from eCommerce.

There are a few theoretical frameworks that might inform the adoption/rejection decisions related to eCommerce. The technology acceptance model (TAM) [8,9] and diffusion of innovation (DOI) theory [10] are the most notable candidates. TAM focuses on the adoption of Information Technology (IT) innovations by individuals. Therefore we did not consider TAM appropriate in our case where the adopting units are organizations. DOI theory has been widely applied to understand the adoption, implementation and diffusion of IT innovations [11]. However, studies of IT innovations have triggered considerable criticism of DOI. Attewell [12], Fichman [13] and Nambisan and Wang [14] demonstrate the complexity of many IT innovations and the technical know-how necessary for their successful adoption, which are poorly addressed by DOI theory.

We also claim that eCommerce exhibits characteristics that affect its adoption but which have not been addressed in the DOI literature. First, we argue that as with many IT innovations, eCommerce is highly evolving. The underlying technology is under continuous development, and its social construction and the technology tend to have high degrees of interpretive flexibility [15]. Consequently, adopting eCommerce is not a single yes or no decision -whether to employ or not to employ the innovation [16]. Instead, the adoption of eCommerce can be conceptualized as a continuous stream of decisions and living with an evolving innovation. Second, auto dealers do not make adopting eCommerce decisions in a vacuum. Dealer decisions are strongly affected by eCommerce adoption by car manufacturers, suppliers, customers, business partners and competitors. DOI theory addresses these interdependencies quite poorly.

Rejecting DOI theory as a frame of reference is also epistemological and methodological. Iivari [17] points out that DOI theory mainly focuses on macro analysis of diffusion of innovations in large populations of potential adopters in contrast to the micro analysis of innovation adoption by a single adoption unit. ${ }^{1}$ The assumption of macro studies has been that the adopting units are basically similar to each other rather than unique cases.

Because of the strategic importance of eCommerce, its evolving nature, its social construction, and the uncertainties and risks involved, we did not consider it appropriate to "force" the casesa priori into a given theoretical framework. Instead, we considered it more appropriate to start with a number of in-depth analyses of comparable retail organizations that we assessed to be at different stages in the eCommerce adoption process (based on analysis

\footnotetext{
${ }^{1}$ This distinction is close but not identical to Attewell's [12] distinction between "macro-diffusion studies" and "adopter studies." However, since Attewell [12] assumes that adopter studies focus on early adopters in contrast to late adopters, he considers diffusion in a large population of adopting units. Orlikwoski's [15] analysis of the adoption of CASE technology is an excellent example of micro study in the sense of Iivari [17].
} 
of their websites). We then generalized from the cases to induce adopter categories and to develop a conceptual model consisting of factors that affect eCommerce adoption. We conducted semi-structured interviews that explored history and implementation of eCommerce in the respective organizations, strategies of eCommerce development, expectations concerning its impact, perceived changes in business, business models and organization, perceived success and critical success factors of eCommerce, and future plans of its development. We expected this to make it possible to respect the richness and uniqueness of cases. Recognizing the potential strategic significance of eCommerce, the interviews were conducted with members of top management of the retailer companies.

The remainder of the article consists of five sections. Section two discusses our research methodology in more detail. Section three analyzes our research findings and suggests a number of adopter categories. Section four introduces a model of eCommerce adoption as a learning process. Section five discusses the implications of the research and, section six presents the paper's conclusions.

\section{RESEARCH METHOD AND CASE DESCRIPTIONS}

Wanting to understand the adoption or rejection of eCommerce as an innovation in retailing that is of strategic importance to the adopting unit, and expecting that the adoption/rejection decision involves much risk and uncertainty, we selected automotive dealerships for our empirical study. The empirical study was done in Finland, which is in many respects an ideal place for a study of this kind. Finland is one of the world's most networked countries. Over 50\% of Finns have mobile phones, a larger percentage than anywhere else in the world. In addition, per capita Internet hosts and Internet traffic volume are the world's highest. Furthermore, 10\% of Finns use the Internet regularly for bill paying and to purchase other services [18]. The general level of education in Finland is high. Thus, salespersons in car dealerships typically have a business or technical college degree, and the computerization in car dealerships is relatively advanced. For example, salespersons typically prepare all documents related to sales on their computers. This high level of computer literacy makes the operational adoption of eCommerce easier. In short, these characteristics make Finland an ideal "laboratory" for studying alternative approaches to eCommerce.

\subsection{Electronic commerce as a strategic innovation in the automotive industry}

For several reasons we decided to select the automotive industry, and especially dealerships, as a specific focus of our study. First, it is expected that the automotive industry will be significantly influenced by eCommerce. Many authors predict that eCommerce will restructure its business models [19, 20]. There already are widely known examples of electronic market places for car sales [21]. These examples indicate that eCommerce is a realistic option that is expected to make auto manufacturers, importers and retailers conscious of the potential changes. Second, the automotive industry is one where delivery of the physical product is an essential part of the process. This means that the market transaction cannot be conducted entirely electronically and that the industry must 
develop a symbiotic relationship between the electronically mediated market transactions and physical logistics. Because of these factors eCommerce is a serious strategic challenge for auto dealers. One can also assume that there is much uncertainty among retailers about the future of the industry, its supply chain, and their position in the chain.

The potential of the Internet for the automotive industry has received worldwide attention. A recent NUA Internet Surveys report [22] mentioned that in excess of $80 \%$ of U.S new car dealers have interactive websites that enable customers to obtain the necessary information to make a purchase decision or to perform the entire car purchase online. The report also stated that over $40 \%$ of customers researched their car purchase decision online. However, only $5 \%$ of those purchasing a new car did so entirely online. Shetty [23] reports equally consistent figures, according to which 57\% of consumers who bought new cars in the past 12 months conducted research online, but only $18 \%$ visited a car-buying website and only $3 \%$ bought online. A different NUA Internet Surveys Report [24] stated that U.K consumers feel comfortable with making purchasing decisions online, but they still prefer a test drive and prefer to buy their car offline.

Even though customer action concerning the online purchase of automobiles is mixed, it is evident that Internetbased eCommerce will greatly impact the automotive industry's value chain [25-27]. Selz and Klein [28] claim that emerging global markets made possible by new electronic media such as the Internet will cause much upheaval in existing automobile markets. These authors investigated in particular how the automotive industry might react to the Internet-enabled arrival of new intermediaries. However, much uncertainty exists concerning the size and direction of these changes. As is often the case in the face of great uncertainty the temptation is to wait it out. Based on a recent field study in Australia, Marshall et al. (2000) concluded that automobile dealers did just that. That is to say, they refrained from taking action. At the dealer level of the value chain one does not know if the Internet's potential presents an opportunity or a threat, whether one will be disintermediated or remain part of the value chain in a new capacity [29].

Finland has several special features that affect the potential adoption and strategic significance of eCommerce. The country has a population of only five million citizens and is one of the largest in Europe by area. Consequently distances between population centers, especially in northern parts of Finland, where the present study was conducted, are great. Competition between dealerships is intense. The agglomeration of Oulu has a population of approximately 250,000 people and yet it is served by eleven major car dealerships. Because of the low population density many dealers operate multiple places of business that are located over a wide geographic area. IT is increasingly used to manage these geographically distributed business sites. Dealers are typically independent firms run by local owners. Many dealers represent multiple manufacturers who do not necessarily belong to the same alliance of manufacturers. Initial conversations with car dealers revealed that automobile manufacturers are closemouthed concerning their contemplated Internet strategies. As a result dealers are in a state of great uncertainty concerning their future role, whether they will play any role at all or be disintermediated altogether. In short, our 
research centers on car dealers, how they perceive their competitive position, and how they plan to capitalize on the opportunities or to counter the threats posed by eCommerce.

\subsection{Case study as a research method and data collection}

The purpose of our research project is to understand how retail companies respond to the opportunities and challenges of eCommerce. In keeping with this purpose we focused on how top management of seven automobile dealerships conceptualized, understood, experienced, and reacted to eCommerce. The seven dealerships were chosen to include companies that were fairly advanced in eCommerce adoption as well as companies that had only recently embarked on using, or had not yet embraced eCommerce. Patton [30] refers to this procedure as purposive maximum variation sampling. Furthermore, instead of relying on a priori theory, we believed that the correct or, perhaps, only way to achieve our goal was to use a qualitative case study approach [31].

Stake [32] differentiates between "intrinsic" and "instrumental" case studies. In an intrinsic case study we wish to learn something about a particular case. Notice that an intrinsic case study is not undertaken because it is representative of other cases, nor because it illustrates a particular trait or problem; rather it is undertaken because the case itself is of interest [33]. In an instrumental case study we aim to learn something beyond the case [34]. That is to say, we aim to understand issues surrounding eCommerce adoption in the retailing industry and to create or sharpen a theory by using cases that originated from the automobile industry. Finally, the potential to generalize results arising from instrumental case studies can, subject to certain limitations, be a good possibility [35]. We applied a multiple case study design to examine eCommerce adoption among car dealerships [36]. The selection of cases followed purposeful maximum variation sampling [37]. The cases were chosen to represent dealerships that are fairly advanced in their eCommerce adoption as well as dealerships that were just at the start or had not yet adopted eCommerce.

Because the authors were associated with the University of Oulu, and in order to keep the project's length and cost within reasonable limits, we selected auto dealers with headquarters in the City of Oulu, Finland. As argued earlier Finland is an ideal "laboratory" for experimenting with alternative approaches to eCommerce. This point is exemplified by a major US-based automobile manufacturer, which currently experiments in Finland with two alternative eCommerce business models. Moreover, the Finnish population is highly educated, prosperous [38], and quite homogeneous. Thus we control these factors.

To ensure that our results would reflect alternative responses to the opportunities and threats of the eCommerce we first contacted by phone the CEOs of the dealerships with and without websites. Next we checked whether dealers would agree to be interviewed. The results of our phone conversations were positive because none of the contacted dealers declined to participate in our study. Our approach yielded a sample of seven from among the eleven major automobile dealers operating in the city of Oulu, Finland. The goal was to select both adopters and non-adopters. In 
this sense the selection of the cases followed theoretical sampling [39]. Five of the seven dealers had adopted eCommerce to varying degrees of sophistication. Two dealers were non-adopters of eCommerce. However, one of the non-adopters became an adopter of eCommerce between our first contact and the subsequent interview.

To enable interviewees to tell their own story we conducted semi-structured interviews. We did not use a questionnaire as such, but instead relied on an interview guideline (see Appendix). We had separate guidelines for adopters and non-adopters. The issues identified in the interview guideline for adopters concerned the history and implementation of eCommerce in the respective organizations, strategies for its development, expectations concerning its impact, perceived changes in the business, business models and organization, perceived success and critical success factors, and future plans. The interview guideline for non-adopters asked, after briefly introducing eCommerce, whether the respondent had considered owning a website, reasons for non-adoption, his/her views of business implications of eCommerce, his/her knowledge of underlying technologies, and his/her understanding of required investments and future plans.

Our aim was to uncover how members of top management experienced and appraised their situation and the extent to which they acted according to their appraisal. In keeping with this aim we took several steps: We tried to avoid distracting situations under which dealers normally operate. Several days before our interview visits we sent dealers a copy of our semi-structured interview guideline. This enabled dealers to reflect on their situation and formulate their opinions. Having the questions before the interview also avoided embarrassing individuals by asking questions they would otherwise have been unprepared to answer. Furthermore, at the start of each interview we attempted to put individuals at ease with small talk. Finally, we let individuals tell their "story" with minimal interruption.

Because understanding the human situation and action is key to our project, an interview-based research method suited our purpose best [40-42]. We conducted one-hour-long, on-site, open-ended, semi-structured interviews with company chief executive officers (CEOs). The interviews were audio taped and then transcribed. Some interviews were conducted in English, others in Finnish, depending on dealer preference.

\subsection{Interpretation of interview data}

Klein and Myers [43] point out that a case study can be positivist, interpretive or critical. They characterize research as positivist when there is evidence of formal propositions, quantifiable variables, hypothesis testing, and inferences drawn about a phenomenon from a representative sample of a stated population. Research is critical if the main task is social critique, and it is interpretive if it is assumed that knowledge about reality is gained through construction such as language, consciousness, shared meanings, documents, tools and artifacts [44]. According to these characterizations, our study is closest to interpretive, even though it resulted in outcomes that may be subjected to a more positivistic testing. Our interest in the interviews centered on how top management of the selected dealerships appraised the opportunities and challenges of eCommerce, how they saw its business meaning and implications, and 
the plans they had for its development. The object of study, eCommerce, was a socially constructed artifact, and top management's appraisal of it is essentially about consciousness, meanings and action. Also our interpretations of the cases are exclusively based on language, tape-recorded interviews, web pages of the participant dealerships and some other company materials.

As mentioned earlier, our practice was to let CEOs tell their own story. However, our printed interview guideline ensured that topics we deemed essential would be raised during the interviews. On returning to the office the authors discussed first impressions of the interview based on memory and notes taken during the interview. After discussing the third interview (Company G, see section 2.4) we noticed that this interviewee' s responses differed radically from those of the two previous interviews (Companies $\mathrm{C}$ and $\mathrm{D}$ ). This sensitized us to the need for comparing and contrasting the dealerships and led us to focus on differences and similarities among dealerships.

To clarify the interpretation process, consider the seven principles of interpretive field research suggested by Klein and Myers [45]. The first principle of the hermeneutic circle suggests that all human understanding is achieved by iterating between the meaning of parts and the whole that they form [46]. We applied this principle most explicitly when contrasting and comparing the seven dealerships. First, we read all seven interviews to form an overall impression. Next, we read each transcribed interview in detail, looking for themes that constitute similarities or differences among the dealerships. This interpretation was a continuous process of keeping an eye on the whole (all seven interviews) while focusing on the parts (each interview).

The second principle of contextualization requires critical reflection on the social and historical background of the research setting, so that the intended audience can see how the current situation under investigation emerged [47]. Our interviews normally started with a lengthy discussion of company history including changes in ownership, the interviewee's background and his/her career with the company. Generally, speaking this helped us to understand the dealerships but, with one exception, this contextual background information did not have a direct connection to the adoption of eCommerce (see section 3.4). For this reason and partly also to keep the anonymity of companies we do not describe this contextual background information systematically here.

The third principle of interaction between the researchers and the subjects requires critical reflection on how the research materials (i.e., "data”) were socially constructed through interaction between researchers and participants [48]. As mentioned above, the interviews were semi-structured, with the interviewers directing the interview to varying degrees. In some cases, most notably in Company $\mathrm{G}$, the interviewee determined the flow of the interview. The interview guideline merely ensured that all topics were discussed. In some cases, the interview proceeded more according to the guideline but never followed it slavishly. So, we are convinced that the interviewees were able to tell their own story without undue influence by the researchers. 
The fourth principle of abstraction and generalization involves relating idiographic details to theoretical, general concepts to describe the nature of human understanding and social action [49]. Klein and Myers [50] argue that connecting individual details to theoretical abstractions and generalizations differentiates an interpretive case study from a simple anecdote. Walsham [51] mentions four types of generalizations that can arise from interpretive case studies: concept development, theory generation, drawing out specific implications, and creation of rich insight. Our study achieved generalizations of the first two types. The adopter categories of section 3 exemplify new concepts, whereas the conceptual model in section 4 represents generating theory.

The fifth principle of dialogical reasoning requires sensitivity to possible contradictions between the theoretical preconceptions guiding the research design and actual findings with each subsequent cycle of revision [52]. The most explicit example of the application of this principle concerns the possibility of disintermediation. Based on extant literature on eCommerce in the automobile industry [53] we initially anticipated disintermediation to be a big concern of car dealers. The interviews, however, revealed that even though dealers were very uncertain about possible disintermediation they did not perceive it as an immediate threat. This in part redirected the focus of research on the resources car dealerships have to survive the possible eCommerce revolution.

The sixth principle of multiple interpretations requires sensitivity to possible interpretations among the participants as typically expressed by multiple narratives or stories about the same sequence of events [54]. Because we targeted members of top management (CEOs) of relatively small companies, we did not have multiple independent informants and therefore we did not apply this principle.

The seventh and final principle of suspicion requires sensitivity to possible "biases" and systematic "distortions" in the narratives collected from the participants [55]. We applied this principle only at the level of assessing whether the respondents were sincere in their responses. Our impression is that the interviewees described very honestly their views of eCommerce in their business. This may be explained by the Finnish practice of giving a direct answer to a direct question. We also sensed that the interviewees did not perceive of eCommerce as a confidential business topic. There was only one case where the respondent was unwilling to describe the content of a contract related to eCommerce.

\subsection{Description of the cases}

We interviewed the CEOs of six dealerships and the liaison manager of a seventh dealership, at the suggestion of its CEO. In one interview the manager of the Oulu site accompanied the CEO. Table 1 shows several dealership characteristics: company background, website presence, website initiator, technology base, and eCommerce comments. Annual turnover in terms of monetary value, and number of new and used cars sold annually vary considerably among the seven dealerships. 
Table 1 shows that all the dealerships except one (A) had their own websites. The websites were subjected to an extensive walk-through analysis. Average website implementation costs are distorted by one dealership (B) whose site was built by two local students at zero-cost. In all other instances the CEO initiated the website's development.

(Insert Table 1 about here)

Even though all dealerships used information systems they varied with respect to their technological maturity. In all companies salespersons, not secretaries, prepared sales documents using computers. As Table 1 shows most of the dealerships were geographically distributed, having a presence in several cities. Three of these dealerships (E, F and $\mathrm{G})$ had networked the geographically distributed sites with fixed lines.

With respect to the future role of the Internet in automobile distribution the opinions of the dealerships varied widely. Although the managers of all seven dealerships agreed that the Internet would impact the automobile industry considerably, they differed with respect to timing. Several managers predicted that the Internet will eventually become an important distribution channel but they saw no immediate need to plan for it. Other dealers felt that the Internet was important already, but only as a marketing channel. Finally, one dealer insisted that actions of the national sales offices of the large automobile manufacturers would determine whether the Internet would be an opportunity or threat for individual dealers.

None of the six companies systematically collected statistics about customer contacts, sales and feedback initiated by e-mail. However, the CEOs of dealerships C, F, and G were well informed about customer use of the websites of their dealerships because e-mails from customers were forwarded to the CEOs by salespersons who originally received the e-mail. Dealerships B and E did not have enough experience at the time of the interview to provide any statistics. Dealerships C and D reported that they quite consistently receive ten to twenty customer contacts in addition to some feedback per month. Company F reported the most customer contacts, about one hundred contacts per month, and estimated sixty-to-seventy used cars sold during the six months prior to the interview on account of referrals from the Internet. The CEO of dealership G estimated about forty customer contacts per month and claimed that he had done much business that originated from the Internet.

Given that CEOs have the responsibility to appoint individuals to take charge of the dealership' s eCommerce effort, they all agreed that new and young employees are better for this purpose. One CEO stated that it is not so much technical prowess that makes a new-hire preferable over a current employee. Rather, it is that the new-hire is not yet settled into a particular way of doing things, does not have to unlearn ways of doing, but can start learning the Internet immediately.

\section{THE EMERGING ADOPTER CATEGORIES}


Table 1 shows that the websites of automobile dealers who had web pages were in many respects quite similar (see section 3.3). However, our interviews revealed that these companies differed significantly in their understanding of the possibilities of the Internet and with respect to their eCommerce strategy. After several readings of interview transcripts it became clear that CEO understanding of eCommerce as a phenomenon could be divided into (1) strategic understanding of the impact of eCommerce on the business model and its consequences, and into (2) technological understandingof the possibilities of eCommerce. In fact, for some CEOs their company's website was very much a foreign artifact. Even when these CEOs knew the functionality of their website they did not demonstrate an understanding of its business implications.

In terms of eCommerce development strategies, it was evident that some companies had adopted a passive strategy whereas others had embraced a much more proactive approach. We termed a strategy passive when a CEO had not adopted eCommerce at the time of the interview or if the dealership had developed a website only to "be ready if eCommerce were to take off" in the car distribution business. On the other hand, dealerships with an active strategy regarded eCommerce as a business opportunity to be enthusiastically embraced (see section 3.4).

\subsection{Strategic understanding}

Business models have received considerable attention in the context of eCommerce. Timmers [56] defines a business model as the architecture for product, service and information flows, business actors and their roles, and a description of the benefits that accrue for each actor. Because business models define the role of dealers in the supply chain, they are of vital significance for dealers. Ford, for example, just launched an eCommerce application in Finland that allows direct buying of new cars from the importer, thus enabling customers to partially bypass the automobile dealer. Electronic Commerce may also lead to other changes in the industry structure.

Underlying business models also emerged as a topic of concern during our interviews. Because of their strategic importance to dealers we call the knowledge and comprehension of business models underlying eCommerce strategic understanding. Generally speaking, there was considerable uncertainty in this respect. Some interviewees articulated ideas of a possible future for eCommerce, whereas other interviewees had a much dimmer view of its potential.

In Company A strategic understanding was clearly very low. The interviewee summarized his contribution, or the lack thereof, at the end of the interview as follows

"? I hope this interview is of some benefit to you. I' $m$ quite unknowledgeable on these issues. I can admit it frankly, because I do not have experience." 
The CEO of Company G was at the opposite extreme. He immediately led the discussion to business models, emphasizing the dealer viewpoint:

“The way organizations, especially car importers, the way they perceive eCommerce, [influences] whether it [eCommerce] is perceived on the field as a threat or as an opportunity. There are two different views in our case, Manufacturer G1 with its own view and Manufacturer G2 with a totally different view. This is very essential because it affects whether there will be competition, whether one sees eCommerce as a threat and starts to "put sticks between the spokes" to compete with it, or whether one sees it as an opportunity and as a tool, and immediately starts to make use of that.",

The strategic understanding of Dealer G's CEO may be explained by the fact that Automobile Manufacturer G2 (referred to in above quote) was active in eCommerce. In other words, the business model underlying eCommerce of Automobile Manufacturer G2 influenced the business of automobile dealership G and the thinking of its CEO.

Company's F interviewee also demonstrated considerable strategic understanding. He described his company's situation as follows:

"We sell cars [from company] F1, F2 and F3. At the moment there is nothing special going on. None of these [manufacturers] is going to start Internet business that bypasses dealers. If you look at their web pages, for example www.F2.yy, there you see which country, and after that it gives the closest dealer. But a big question is how it will be done in the future. As a matter of fact, there are distribution systems delivering cars directly to the front door of the customer. (? .) In England Volkswagen sells two car makes through the Internet at prices that are 900 pounds lower than normal. The cars are delivered to the dealer who gets a nominal payment for final customer delivery, giving keys and washing the car."

He also took issue with reintermediation, as exemplified by Auto-By-Tel's attempt to invade the Finnish market.

The representatives of the remaining three companies demonstrated a more intermediate strategic understanding with regard to eCommerce. They recognized that eCommerce will likely make it easier for customers to compare prices (Company D), will likely decrease price differentials among regions of the country (Companies B and E), will make the business of regional car dealers more nation-wide (Companies $\mathrm{C}$ and $\mathrm{E}$ ), and may lead to separation of selling new and used cars (Company $\mathrm{C}$ ). However, none of the CEOs demonstrated an equal systematic understanding of the strategic significance of eCommerce, and they did not raise this issue themselves.

\subsection{Technological understanding}

\footnotetext{
${ }^{2}$ For anonymity the real names of manufacturers are concealed.
} 
Technological understanding refers to the respondent's comprehension of eCommerce as a technological phenomenon, namely, how it is supported by information and communication technologies, especially the World Wide Web, and what functionalities it may have. The respondents' technological understanding on the whole followed a pattern similar to their strategic understanding. The CEO who admitted that he had never used e-mail and that he did not know what World Wide Web meant, explained his lack of knowledge as follows:

“It is mainly because I do not have language skills that I' $m$ behind, I master these basic programs [for car dealers] but this side is a little bit [weak]"

Companies C, D and E had their own web pages. However, even though the interviewees from these companies were aware of the functionality of their websites, the websites remained external artifacts. They saw eCommerce as merely an external factor they needed to adapt to (Company C), as an opportunity (Company E) or as a new marketing channel (Company D). These respondents did not demonstrate a sophisticated understanding of the business meaning of their websites in the sense of the potential functionality in supporting eCommerce, as did the respondents of companies F and G.

The representative of Company F strongly emphasized the Internet as a two-way information channel between customer and seller. He saw this two-way nature as so important that he claimed:

"In my opinion the Internet is to make customers more loyal. Through the Internet you can create "frequent customer" benefits and special offers and be in contact [with the customer] directly through e-mail."

This view is clearly at odds with the myth that "Open IT network architectures lower prices and benefit buyers as the dependence on supplier hierarchies is reduced" [57]. However, the representative of Company F stated that since the Internet, prices have clearly become more equal among different parts of the country.

Company G stated right at the start of the interview:

"To me eCommerce does not require that a business transaction is conducted electronically [in its entirety]; there is eCommerce if a customer during some stage of the process is in contact with us electronically, using an electronic media. In my opinion that is eCommerce. Often eCommerce or Internet-commerce is assumed to cover the whole process from the beginning (A) to the end (Z) electronically."

He also demonstrated his technical understanding by critically commenting on his company's website:

"Yes, in my view it [website] has collected dust. It has not been touched for a couple of years. They were pretty good when they were installed, but now they definitely are outdated." 


\subsection{Website maturity}

The assessment of website maturity was based on an overall evaluation of its current functionality on a dealer-bydealer basis (Table 1). Because of commonalities within the industry, it is understandable that there is considerable similarity among the six sites. On the other hand, there are also some differences. One of the major differences concerns used cars. In the simplest case the website just displayed a simple list of used cars, with the list being maintained manually (Companies C and D). As a more advanced solution the website may include a search engine that allows specifying several search criteria for finding cars of interest from an underlying database (Companies $\mathrm{E}$ and F). As an intermediate solution, there may be a search engine that is manually integrated with the company's database (Company G). A second clear difference in website functionality concerns customer service. For example, two of the dealers had implemented online booking for maintenance and repair service (Companies $\mathrm{E}$ and $\mathrm{F}$ ). Furthermore, two dealers attempted to personalize their websites by having photos of their personnel accompanied by contact information (Companies B and E).

\subsection{Electronic Commerce developmental strategy}

The seven car dealers showed great differences with respect to their eCommerce developmental strategies. For example, the CEO of Company A had decided not to adopt eCommerce. To the interviewer's comment that many competitors had adopted, he replied:

"No, it does not create any pressure. We sell well and we have customers, and I don't believe that they [my competitors] are selling much over it (Internet)."

He then continued:

"I think that it will be the next generation that will start with it, because I' $m$ so far over 50. Let us see whether my sons will continue [the business] and so on; they have more knowledge."

He estimated that his company might adopt eCommerce within the next five years.

Company B installed its own website in 2000. Even though the CEO of Company B did not state so directly, based on his revelations we deduced that the offer of two young students to develop Web pages free of charge was a significant reason for its development. The students had actually configured a rather professional looking website as part of a school course assignment. This chain of events suggests that the dealership's management 1) experimented with the Internet but yet lacked a clear strategy and 2) did not consider hardware or website maintenance expense. In 
other words management acted opportunistically. The CEO did not report any specific future plans and his idea that the two students would take care of the future website development and maintenance did not sound very believable.

Company $\mathrm{C}$ and Company $\mathrm{D}$ also had a rather passive strategy of going along with eCommerce in order to be ready when it would really take off. Their web pages were unsophisticated. The CEO of Company C planned to develop a way for customers to schedule car maintenance appointments on a website. Finally, the CEO of Company D expressed the intention of improving the company's website gradually.

In contrast to the companies discussed above, companies $\mathrm{E}, \mathrm{F}$ and $\mathrm{G}$ evidenced a much more proactive development strategy. The interviewees from Company E were visibly pleased with the opportunity to discuss their web pages with university researchers, even though the company's web pages were not entirely finished at the time of the interview. They strongly emphasized their belief that eCommerce is an opportunity and they actually saw it as a major risk not to be involved. With respect to the future, however, their company needed to slow down and take stock of its eCommerce efforts and future plans.

The interviewees from Companies $\mathrm{F}$ and $\mathrm{G}$ also considered eCommerce a business opportunity in which they had to be involved. In addition, both interviewees expressed a considerable commitment for further eCommerce development. The respondent from Company $\mathrm{F}$ told the interviewers that planned investment for further development of eCommerce was in the range of 13,000 to $16,000 €$ (Euro). More specifically, his plans included development of extranets specific to each of the company's industrial customers. Company F had also created a managerial position responsible for further IT developments.

Company $\mathrm{G}$ also demonstrated considerable commitment to development of IT capabilities, including eCommerce. It had incorporated IT in its strategic plan and had nominated an individual with a business background as its IT manager. The CEO of Company $\mathrm{G}$ also demonstrated great interest in and considerable understanding of IT. As mentioned earlier he saw his company's web pages as outdated and he had committed to a considerable updating effort. More specifically, this CEO raised issues of service bookings through the Internet, development of extranets specific to the company's customers and exploitation of mobile telephone technology so that, for example, upon service completion the system would automatically send a short message to the customer's mobile phone stating that the car was ready for pickup. He also selected several other IT development projects such as, electronic archiving. In fact, he gave the impression that further company website development was delayed by other development projects. Despite these concerns one could clearly sense that the company planned to be proactive in the use of eCommerce.

\subsection{Adopter categories}

Figure 1 summarizes our ranking of the seven dealers on four dimensions: strategic and technological understanding, website maturity, and eCommerce developmental strategy. It is evident that Company A ranks lowest 
and companies F and G rank highest in strategic and technological understanding. Companies B, C, D and E occupy intermediate positions on strategic and technological understanding. Based on our interview data it is difficult to identify any difference in understanding dimensions among companies B, C, and D. Figure 1 also shows that Companies $\mathrm{E}$ and $\mathrm{F}$ employed the most advanced web pages and, hence, ranked first on the website maturity dimension. Furthermore, our evaluation indicated that Company B ranked second and companies C, D and G ranked third. Company A is an extreme case because it lacks a website and, hence, is considered the least mature. In terms of an eCommerce developmental strategy, one easily identifies five cases: Company A decided to wait and see instead of adopting, Company B used an opportunistic strategy, Companies C and D used a passive adoption strategy, Company E showed an active adoption strategy but lacked clear future plans, and Companies $\mathrm{F}$ and $\mathrm{G}$ evidenced a proactive strategy that included clear future plans and a strong organizational commitment to eCommerce.

It is notable, however, that the rankings of the seven companies on the four dimensions are quite consistent (Figure 1). Company A shows the lowest ranking on all four dimensions, companies $C$ and $D$ rank in the middle, and Company $\mathrm{F}$ ranks highest on all dimensions. Most differences among company rankings on the developmental strategy are minor. As previously noted Company B ranks in the middle on all dimensions except for its eCommerce developmental strategy and for its website maturity. Similarly, Company E ranks in the middle except for its developmental strategy and its website maturity. Company B shows the largest spread between its rankings compared to other companies: the company ranks second on technological understanding and fourth on eCommerce developmental strategy.

\section{Include Figure 1 about here}

The high consistency of the rankings along the four dimensions led us to conjecture that one can identify emerging adopter categories or gestalts that synthesize the four dimensions, as shown in Figure 1. We called them emerging gestalts because they are inductive generalizations based on qualitative data obtained from a limited number of cases. As in quantitative cluster analysis we do not expect unique solutions to this categorization problem, but meaningfulness of the resultant clusters must be evaluated in terms of the distribution of the cases into clusters, the homogeneity of clusters, and the ease of their interpretation. In our study, with its small number of cases, it is not meaningful to focus too much on the distribution of the cases into categories. Instead we emphasize faithfulness to the data, reasonable homogeneity of categories, and the interpretability captured by the descriptive name of the cluster. Figure 1 identifies two mutually consistent solutions to this qualitative cluster analysis problem. The first solution identifies three clusters:

? "Procrastinators" as exemplified by Company A. They have decided not to adopt eCommerce at the present time but to wait and see. Their strategic and technological understanding of eCommerce is low, and the maturity of their websites is also low. 
? "Followers" as exemplified by companies B, C, D and E. They have adopted eCommerce but they do not attempt to lead its development. Their strategic and technological understanding of eCommerce is intermediate. Website maturity varies but on the whole it is intermediate.

? "Visionaries" as exemplified by companies G and F. They demonstrate high degrees of strategic and technological understandings, a mature website, and an active eCommerce developmental strategy. With respect to the seven cases only F ranked first on all four dimensions. As pointed out above, Company G differed from this characterization because it ranked first on three dimensions but only third on the maturity dimension. It is, however, our belief that this situation is temporary.

Our data showed, considerable variation among "followers" especially in their eCommerce development strategy. In order to emphasize this variation, "Followers" was further divided into three categories:

? "Opportunists" as exemplified by Company B. On account of some special circumstances opportunists have adopted eCommerce but they lack any clear strategy. In fact, strategic and technological understanding of eCommerce tends to be low, and the maturity of the website is also relatively low. As mentioned above, Company B may not be able to maintain its relative position on the maturity dimension if it does not change its eCommerce developmental strategy.

? "Waverers" as exemplified by Companies C and D. They have adopted eCommerce in order to gain experience so as to be ready if eCommerce takes off. Strategic and technological understanding by these companies and the maturity of their websites tend to be average.

? "Striders" are exemplified by Company E. They have a fairly proactive strategy and attempt to gain rapid progress in their eCommerce deployment. This progress usually arises on account of externally induced developments of relatively advanced web pages. A critical question in the case of "striders" is whether they are able to maintain the momentum and build corresponding strategic and technological understanding.

\section{ADOPTION OF ELECTRONIC COMMERCE AS A LEARNING PROCESS}

Even though some dealerships (such as $\mathrm{C}$ and $\mathrm{F}$ ) maintained websites in support of eCommerce for approximately the same length of time, their understanding of the phenomenon differed radically. This shows that creation and operational use of a website are insufficient to trigger effective learning about eCommerce. This observation led us to conceptualize eCommerce uptake as a learning process (Figure 2). The figure presents a conceptual model containing potentially relevant factors in the adoption of eCommerce among car dealers. The model represents an inductive generalization of seven cases; it is therefore, hypothetical. The purpose of the present section is to explain our model so that it can be the basis for further research.

Insert Figure 2 about here 
With one exception our interviewees were CEOs of their dealerships. It is obvious that adoption of any significant innovation in small or medium sized companies such as Companies A through $\mathrm{G}$ requires top management' $\mathrm{s}$ acceptance and continued commitment. The interviews also revealed that CEOs' interest in IT varied radically for several reasons. For example, the CEO of Company $\mathrm{G}$ expressed his personal interest in various IT gadgets. The eCommerce initiatives of some manufacturers he represents may also explain some of his interest. We did not interview the $\mathrm{CEO}$ of Company $\mathrm{F}$, but we sensed that his position in the national association of auto dealers in Finland might explain his interest in eCommerce.. The interest of Company E's CEO may have arisen because of one local manager's interest in eCommerce and because of the eCommerce initiative of one of the major manufacturers he represented. The CEO of Company A referred to his age and uncertainty about his successors as a reason for his disinterest in eCommerce.

Rogers [58] asserts that organizational size is positively related to innovativeness. Swanson [59], while agreeing with Rogers, also proposes that early adoption of Type II innovations (applying IS products and services to core business administrative processes) and Type III innovations (integrating IS products and services with core business technology) is more likely when host organizations are large and diversified. Electronic Commerce is a clear example of a Type III innovation. Our findings are in agreement with Rogers' [60] and Swanson's [61] assertions because larger dealerships in our study tended to be more advanced in eCommerce adoption than smaller dealerships (Table 1). Rogers [62] suggests a number of reasons for the significance of size: total resources, slack resources, technical expertise of employees, organizational structure, et cetera. In our case it was obvious that larger dealerships (Companies F and G) had more resources to invest in the adoption of innovations such as eCommerce and the hiring of IT managers.

On the other hand, we do not claim that the size has a positive effect and still less a simple linear positive effect over the entire range from small firms with few employees to large firms with thousands of employees. All the dealerships in our study have fewer than 200 employees. In fact, a recent survey of the adoption of web technology, covering a number of industries with larger companies, did not find organizational size to be related to the adoption of web technology [63]. We also wish to point out that even though company size may be relevant in statistical terms, the relationship is not necessarily so deterministic that the larger company would always be more advanced in eCommerce than the smaller company. In fact Company D in our study, the second smallest of the seven dealerships, was clearly more active than Company B.

A third "external" factor that clearly stood out during the interviews was IT application maturity. For example, salespersons in all seven companies use computers to do the paperwork related to auto sales. A distinguishing factor, however, was the use of information and communication technologies to manage geographically distributed companies. Companies E, F, and G had networked their geographically distributed organizational units. The CEO of Company $\mathrm{G}$ emphasized the significance of networking as shortening the geographical distance between the units. It may well be that experience with networking provided a head start towards establishing web pages for eCommerce. 
As Table 1 shows, networked companies were larger than non-networked companies. In short, company size may partially explain differences in IT maturity among companies.

There were also clear differences in respondents' beliefs about eCommerce. CEOs of Companies A through D expressed the conviction that eCommerce was coming, but they did not see its significance for the business just now. Respondents from Companies $\mathrm{E}$ through $\mathrm{G}$ saw eCommerce much more as an immediate opportunity that had to be embraced. Based on our interview data we do not know if the beliefs expressed motivated CEOs to adopt eCommerce. It is also possible that CEOs formed these beliefs merely as rationalizations of their decision to participate in eCommerce. However, previous research [64] indicates a mutual dependency between beliefs and strategic and technological understanding of eCommerce. One can hypothesize that strategic and technological understanding affects an organization's absorptive capacity [65] with respect to eCommerce. Cohen and Levinthal [66] argue that absorptive capacity influences expectation formation because better knowledge permits companies to better understand and therefore better evaluate the commercial potential of technological advances. Because of low strategic and technological understanding of eCommerce a company may not be aware of eCommerce opportunities. This naturally influences the adoption of eCommerce.

As pointed out above, dealership rankings on the four eCommerce adoption dimensions of Figure 1 are highly consistent. Figure 2 suggests that they may be causally related. We take strategic and technological understanding of eCommerce to influence both eCommerce developmental strategy and website maturity. This causal relationship between strategic and technological understanding of eCommerce and its developmental strategy is consistent with Cohen and Levinthal [67]. They propose that organizations with higher levels of absorptive capacity tend to be more proactive than organizations with more modest levels of absorptive capacity, which tend to be more reactive. We further assume developmental strategy to influence website maturity, at least in the long run (Company G being an exception, at least in the short run). Figure 2 shows that strategic and technological understanding of eCommerce can also influence website maturity more directly, without any change in the developmental strategy. This may occur when, for instance, an external vendor uses state-of-the-art website technology to implement a sophisticated website for a company.

We observed striking differences in strategic and technological understanding of eCommerce among Companies C, $\mathrm{D}$ and $\mathrm{F}$ despite the roughly equal longevity of their websites. Assuming that strategic and technological understanding of eCommerce were poor to the same degree in the three companies three to four years ago, one has to wonder what factors explain the present differences among these three dealerships in the accumulation of the strategic and technological understanding of eCommerce. One possible explanation is that the companies differed in IT maturity and experience. Especially relevant factors may include prior Internet experience by Company F and hiring a manager with computing expertise. Put differently, it may be that prior Internet experience and the presence of a manager with IT experience created an environment conducive to eCommerce development. 
Cases $\mathrm{C}$ and $\mathrm{D}$, on the other hand, indicate that development of a website in support of eCommerce is by itself insufficient to trigger effective learning at the level of strategic and technical understanding of eCommerce. Even though Companies $\mathrm{C}$ and $\mathrm{D}$ implemented rather mature websites early on, they did not manage to initiate effective organizational learning. We suggest that this may be because of their fairly passive strategy regarding eCommerce development. On the other hand, Companies $\mathrm{G}$ and $\mathrm{F}$ have been much more successful in this respect. In short, Figure 2 suggests that organizational learning -- strategic and technological understanding of eCommerce -- depends not only on the maturity of the website but also on the eCommerce developmental strategy. This assumption derives from our analysis of the eCommerce adoption paths in the seven automobile dealerships.

\section{DISCUSSION}

We concluded in section 3 that the seven dealerships and their business conditions are configurable into adopter categories, each with four dimensions (Figure 1). We identified three major categories: "procrastinator", " follower", and "visionary" . "Followers" were further divided into three subcategories: “opportunist," "waverer," and "strider." Each category in turn is characterized by four dimensions: "strategic understanding", "technological understanding", "website maturity", and "eCommerce developmental strategy." As already mentioned in section 3 "strategic understanding" and "technological understanding" refer to the company's appreciation of the impact of eCommerce on the business model and technological possibilities, respectively. "Website maturity" reflects website functionality and "developmental strategy" reflects the company's strategy towards implementing its eCommerce capability. It is noteworthy that these adopter categories do not correspond to Rogers' [68] five adopter categories based on the earliness of adopting (innovators, early adopters, early majority, late majority and laggards) because we do not attempt to describe the timing of adoption. Company $\mathrm{G}$ was an early adopter and Company $\mathrm{B}$ a late adopter. Companies C, D and F adopted approximately at the same time. However, Company F differed considerably from Companies C and D. Another clear difference from Rogers [69] is that we do not see a company's membership in an adopter category as fixed or permanent. Finally, the categories we identified are not stages in a predetermined sequence. For example, Company $\mathrm{E}$ as a strider made a quick move from a non-adopter to a fairly advanced stage.

Our inductive analysis of seven cases led to a theoretical model (Figure 2) that has several affinities with the resource based view (RBV) of competitive advantage [70-71]. ${ }^{3} \mathrm{RBV}$ has also aroused interest in the IS community [72-76]. These studies focused on large organizations, whereas our study concerns small companies. However, Hadjimanolis [77] claims that RBV is particularly suitable in the case of small firms. This makes the RBV potentially relevant to our study. The role of the owner or the manager as an organizer of resources and as an orchestrator of strategy in small firms [78] is in line with Figure 2, which emphasizes the significance of top management's leadership or entrepreneurial ability [79] as a special resource. Entrepreneurial ability is the capacity to identify, develop, and complete new combinations of existing asset bundles into new asset configurations [80]. 
Analysis of our interview data does not allow us to claim that eCommerce yielded any of the seven companies a significant competitive advantage. In fact, Godfrey and Gregersen [81] suggest that current scholarship in RBV focuses more on the nature of resources than their linkage with competitive advantage. Barney [82] distinguishes three types of resources: physical capital, human capital, and organizational capital. Physical capital represents technology, production equipment, and the firm's geographic location. Human capital includes employee knowledge, experience, training, and insights. Organizational capital stands for planning, controlling, and coordinating procedures, and relations among people within the firm and relations between the firm and outside organizations. Based on the above analysis it is clear that our seven companies differed with regard to their resources such as IT maturity and website maturity, human resources such as IT experience and strategic and technological understanding, and organizational resources such as top management leadership and eCommerce developmental strategy (Figure 2).

Our findings are consistent with the point made in RBV theory that tangible resources are easier to imitate than intangible ones [83]. If we consider website maturity as a tangible resource, it is then obvious that it can be imitated quite easily by employing external consultants, as was noted by Company G's CEO as well as practiced by Company E. RBV also predicts that intangible resources such as knowledge are much more difficult to imitate [84, 85]. As a result, RBV theory focuses on knowledge as a critical resource. In fact, Teece et al. [86] suggest that the greatest contribution of RBV theory to strategy formation involves skill acquisition and the management of knowledge and learning. This is consistent with Figure 2 which identifies two types of knowledge (technological and strategic understandings of eCommerce) that are pivotal to eCommerce adoption. More specifically, technological and strategic understandings of eCommerce relate closely to managerial IS skills among the four ITrelated resources: capital, proprietary technology, technical skills, and managerial IT skills discussed by Mata et al. [87] from the RBV perspective. ${ }^{4}$ Based on their analysis of the value of resources, their heterogeneous distribution and imperfect mobility, these authors conclude that managerial IT skills alone are the basis for a sustained competitive advantage. ${ }^{5}$

\footnotetext{
${ }^{3}$ For the sake of simplicity, we do not make distinctions between resources, services rendered by resources, assets, capabilities and competencies, as are made in the RBV literature. One should also note this vocabulary is not well established in RBV.

4 Note, however, that IT skills in Mata et al. (1995) concern skills of IT managers and not IT skills of general managers such as CEOs. Most auto dealers in our study did not have a separate IT function or manager.

${ }^{5}$ Bharadwaj (2000) criticizes Mata et al. (1995) for a reductionist view of technology, which considers technology to consist of commodity-like components, ignoring architectural aspects of the IT infrastructure. Bharadwaj (2000) claims that building such an integrated infrastructure takes time and effort. Our data do not allow conclusions about the mobility of IT infrastructure as a resource. We note, however, that we focused on small companies where the IT infrastructure may not be as complex to develop as in larger organizations. Despite these considerations, our data led us to acknowledge the significance of IT infrastructure and IT maturity as a determinant of the eCommerce adoption process.
} 
Much recent research on RBV is informed by the idea of a hierarchy of "resources," namely, undifferentiated production factors, firm-specific assets, competencies and capabilities [88-93] ${ }^{6}$. Because of the limitations of our interview data, it is beyond the scope of this study to analyze in-depth the competencies and capacities of the seven dealerships. Instead, Figure 2 should be interpreted as a model of the resource accumulation process at the level of firm-specific assets, focusing especially on knowledge assets (technological and strategic understandings of eCommerce). In fact, Priem and Butler [94] and Barney [95] agree that RBV has neglected the asset accumulation process.

Previous research suggests, however, that knowledge and learning are pivotal in these higher-level competencies and capabilities [96, 97]. Grant [98] proposes that a capability is essentially about knowledge integration. Even though we did not attempt to identify and assess capabilities of the seven dealerships, one should note that technological and strategic understandings of eCommerce imply aspects of knowledge integration: higher technological and strategic understandings can be expected to facilitate the integration of eCommerce with the company's business. Teece et al. [99] claim that organizational competencies and capabilities reside in organizational processes, emphasizing the importance of learning processes. Figure 2 emphasizes learning as an accumulation of technological and strategic understandings of eCommerce. Technological and strategic understandings of eCommerce, when they broaden dealerships' understanding of the possible functionalities of eCommerce and underlying business models, can also be expected to enhance the dealership's dynamic capabilities, i.e., quoting Teece et al. [100]: “the firm's ability to integrate, build, and reconfigure internal and external competences to address rapidly changing environments."

As observed above, we found striking differences in strategic and technological understandings of eCommerce between the companies and their learning trajectories. This leads us to the question of what factors may explain the differences in the accumulation of the strategic and technical understandings of eCommerce. Figure 2 suggests that organizational learning, building strategic and technological understandings of eCommerce, depend not only on the maturity of the website but on the combination of website maturity and the eCommerce developmental strategy. A related question is whether companies with less advanced strategic and technical understandings of eCommerce will be able to catch up with companies with more advanced strategic and technical understandings. This is illustrated by Company E, which has clearly adopted a proactive strategy and established an advanced website. Will it be able to increase its technological and strategic understandings (as Figure 2 would suggest) and eventually catch up with Companies F and G? The path dependence of absorptive capacity, implied by strategic and technological knowledge [101] and time compression diseconomies [102] suggest that this would be difficult to accomplish. The point is that "accumulating" absorptive capacity in one period will permit its more efficient accumulation in the next [103]. Therefore an early start is important. But as pointed out earlier, we suggest that an early start alone is insufficient. It should be accompanied by an active eCommerce developmental strategy.

${ }^{6}$ Our use of the term "resources" refers to production factors, firm-specific assets, competencies and capabilities (see Teece et al.. 1997.) 
Our study suggests that degree and kind of eCommerce uptake should not be determined solely by studying a company's website. ${ }^{7}$ Website maturity is certainly indicative and is a manifested expression of technological adoption of eCommerce. But we suggest that it is not necessarily indicative of a sound eCommerce adoption policy. A sophisticated website can be created relatively easily by an external developer. However, if a dealership does not have adequate strategic understanding and technological understanding of eCommerce, along with an eCommerce adoption strategy, the externally developed website may not be properly integrated with the business.

We will emphasize this point with a metaphor. Consider the sport of "orienteering" which is popular in Finland. A participant has to find certain places in an unknown terrain with the aid of only a compass and a map. One may have the compass, but he may not know how to use it. Or he may have a map but he may not be able to locate himself on it. Or he may not be able to read the map, or to select a proper strategy when choosing the route. Either way he will fail to reach the target location.

Similarly, a dealership or company may have a technologically advanced website but may not be able to use it in its business. It may lack a map of the business terrain, especially one over the immediate time horizon. It may not able to locate its position on the map. It may lack the necessary strategic and technological understandings of eCommerce and the developmental strategy to get where it wants to go. Therefore, our advice for researchers and practitioners is to not only look for website maturity but also to consider the eCommerce strategic understanding, technological understanding, and eCommerce developmental strategy.

As mentioned in section 2.4 none of the companies systematically collected statistics about eCommerce. However, Companies $\mathrm{F}$ and $\mathrm{G}$ reported much more positive numbers than Companies $\mathrm{C}$ and $\mathrm{D}$, that had approximately the same experience. None of the companies reported cases where the entire market transaction except delivery had been conducted electronically. There are a number of technical, legal and cultural factors that may explain this conservativeness [104]. First, despite an advanced technical infrastructure, the Finnish shopping culture is not necessarily amenable toward buying cars electronically. For example, shopping from catalogues has never been particularly popular in Finland. Second, cars are very expensive in Finland. Therefore a car is a major investment for Finnish households. This may lead to increased use of the Internet to gather background information and do comparative shopping, but the final decision is not necessarily made online. Third, sales of new cars and old cars are not separated in Finland. When a customer buys a new car he or she normally expects the dealership to buy back his or her old car. That makes the negotiation complex because part of the deal is to agree upon the value of the trade-in. Even though the car dealers predicted that these business practices would change, it will likely take some time.

\footnotetext{
${ }^{7}$ There is a tendency to rely on the concrete and visible web pages partly because of their easy accessibility (Liu et al., 1997; Palmer and Griffith, 1998).
} 
One could also claim that the number of car sales initiated by the Internet is not necessarily a good indicator of the success of a dealership's eCommerce policy. Perhaps, it is more fundamental to think of a company's eCommerce policy in terms of how it helps to position the company for the future. For example, there is a clear trend of expanding eCommerce to support auto service. Two companies (E an F) already had web pages that allow booking service time online, and two other companies (C and G) had plans to develop their websites with that feature.

As an outcome of the above analysis, we do not assume that eCommerce adoption is directly related to the amount of business conducted electronically. Naturally, IT supporting eCommerce is a necessity, but after that consumer behavior may be influenced by a variety of factors not considered in this paper.

What are the implications of the study for practice? We contend that eCommerce is such a significant phenomenon affecting car dealers that they should be aware of it. Therefore we wish to emphasize the primacy of strategic and technological understandings of eCommerce instead of website technical maturity. Our interview-based study positively identified two key enablers: strategic and technological understanding. Companies with better strategic and technological understandings have better opportunities to respond in an appropriate way to contingencies created by future eCommerce developments and to survive under these new business situations. Even though these enables are difficult to develop and/or imitate we encourage dealerships to invest in them. Furthermore, although an advanced website may not be vital for this learning, it nevertheless may create a concrete impetus. As discovered above, the cost of building a reasonable and informative website is not very high. However, as pointed out by Keen and Balance [105], construction costs are moderate as long as sales transactions against the website are not required. In addition, a company must have an active developmental strategy and an active interest in the phenomenon. The goal could be to initiate a positive learning cycle that reinforces understanding and further development.

\section{CONCLUSIONS}

We undertook this study because we were interested in the way retailing executives react to the uncertainty created by the penetration of eCommerce into their markets. We selected the automotive industry and particularly car dealers for our study because, based on previous research [106, 107], we expected it to be heavily influenced by eCommerce. Finland was an ideal country in which to conduct our research because it is technologically advanced and populated by citizens who are avid users of Internet technology. Furthermore, a major U.S-based car manufacturer is experimenting with two alternative strategies for online automobile purchasing in Finland. This fact implies a greater possibility that automobile dealers have considered the potential impacts of eCommerce on their business. In fact, our interviews demonstrated that all but one dealer had given serious consideration to the effects of the Internet and eCommerce on their business.

Our interviews indicated that the CEOs did not perceive the possibility of disintermediation as an immediate threat. However, their reactions to the emergence of eCommerce and responses to our interview questions differed 
strikingly. This led us to focus on similarities and differences among the dealerships, which ultimately crystallized into four themes or dimensions: strategic understanding of eCommerce, technological understanding of eCommerce, website maturity, and eCommerce developmental strategy. Ranking the seven companies along these four dimensions showed clear patterns. Even though some dealerships had equally long histories of having a website supporting eCommerce, their understandings of the phenomenon differed radically. Thus, we conclude that the existence of a website as such and its operational use is not sufficient to trigger effective learning about eCommerce. This led us to hypothesize the adoption of eCommerce as a learning process, as depicted in Figure 2.

The study's limitations arise from the small number of retailers in one industry, in one city, and in one country. The extent to which the study's findings can be generalized beyond the seven cases, beyond Oulu, beyond Finland and beyond the automobile industry is a question to be addressed in future research. Our case study targeted CEOs of dealerships and, hence, obtained data from one respondent per company. More generally, we did not have an opportunity for triangulation because most of the discussion concerned issues which only the CEOs were able to answer. However, as pointed out in section 2.3, we judged their responses to be honest and sincere.

Our study took place during a specific time period, which may affect our results. Knowledge and learning as discussed in Knowledge Management for example, are very popular concepts at the present time. This fact combined with our academic background may have biased us to focus on knowledge resources. At the same time, we focused on a period of change and unpredictability from the viewpoint of the seven dealerships. Miller and Shamsie [108], in their analysis of Hollywood studios, found that property-based resources helped financial performance in a stable environment, whereas knowledge-based resources boosted performance in a more uncertain environment. Since our study targeted the adoption process of eCommerce, which as a major innovation involves considerable uncertainty, we believe that our emphasis on knowledge is justifiable and consistent with previous research.

Despite the above limitations the study succeeds in creating theoretical insights into eCommerce uptake in retail businesses. These results suggest several avenues for future research. More specifically we see a need for future research on three fronts:

- Longitudinal studies of eCommerce adoption in individual retail businesses. The present study underlines that the adoption of an evolving innovation such as eCommerce is a continuous process (as suggested in Figure 2). In order to achieve a deeper understanding of the dynamics, in-depth longitudinal studies of the adoption of eCommerce in individual companies are required. The retailers to be investigated may operate in the automobile industry or in other retail businesses.

- Surveys to test the generalizability of the adopter categories (Figure 1) and the causal model (Figure 2). Surveys allow data collecting from a larger sample of retailers dispersed over a greater geographic area. The surveys may be targeted to other retail businesses, allowing testing of generalizability across industries. 
- Cross-cultural analysis of eCommerce adoption in automotive retailing and other businesses.

We plan to contribute on all three fronts in future studies.

\section{ACKNOWLEDGMENTS}

This research received support from the Office for International Studies, University of Missouri - St. Louis, USA, and the Department of Information Processing Science, University of Oulu, Finland. We are grateful to the eight interviewees for their time and cooperation. We also wish to express our gratitude to the reviewers of the paper. Especially helpful was one reviewer's suggestion to contrast our findings with the resource-based view of organizations.

\section{References}

[1] Shaw, M. J., "Electronic Commerce: Review of Critical Research," Information Systems Frontiers, Vol.1, No.1, 95-106, 1999.

[2] Benjamin, R., and Wigand, R., "Electronic markets and virtual value chains on the information superhighway," Sloan Management Review, 62-72, 1995.

[3] Kalakota, R. and Robinson, M., e-Business: Roadmap for Success, Reading, MA: Addison Wesley, 1999.

[4] Kalakota, R, and Whinston, A., Electronic Commerce: A Manager's Guide, Reading, MA: Addison Wesley, 1997.

[5] Malone, T. W., Yates, J., and Benjamin, R. I., "The logic of electronic markets," Harvard Business Review, May-June, 166-172, 1989.

[6] Hart, C., Doherty, N. and Ellis-Chadwick, F., "Retailer adoption of the internet, Implications for retail marketing," European Journal of Marketing, Vol.34, No.8, 954-974, 2000.

[7] Chircu, A., and Kauffman, R. J., "Strategies for Internet Middlemen in the Intermediation / Disintermediation/Reintermediation Cycle," Electronic Markets, Vol.9, No.1/2, 109-117,1999.

[8] Davis, F.D., "Perceived usefulness, perceived ease of use, and user acceptance of information technology", MIS Quarterly, Vol.13, No.3, 319-339, 1989.

[9] Davis, F.D., Bagozzi, R.P. and Warshaw, P.R., "User acceptance of computer technology: A comparison of two theoretical models," Management Science, Vol.35, No.8, 982-1003, 1989.

[10] Rogers, E.M., Diffusion of Innovations, 4th edition, New York, NY: The Free Press, 1995.

[11] Prescott, M.B. and Conger, S.A., "Information technology innovations: A classification by IT locus of impact and research approach," The DATA BASE for Advances in Information Systems, Vol.26, No.2 \& 3, 20-41, 1995.

[12] Attewell, P., "Technology diffusion and organizational learning: The case of business computing", Organization Science, Vol. 3, No. 1, 1-19, 1992.

[13] Fichman, R. G., "Information technology diffusion: A review of empirical research", DeGross, J.I., Becker, J.D. and Elam, J.J (eds.), Proceedings of the Thirteenth International Conference on Information Systems, Dallas, TX, 195-206, 1992.

[14] Nambisan, S. and Wang, Y. -M., "Web technology adoption and knowledge barriers," Journal of Organ izational Computing and Electronic Commerce, Vol. 10, No. 2, 129-147, 2000.

[15] Orlikowski, W.J., "The duality of technology: Rethinking the concept of technology in organizations," Or ganization Science, Vol. 3, No. 3, 398-4271992.

[16] Fichman, R.G. and Kemerer, C.F., "The illusionary diffusion of innovation: An examination of assimilation gaps", Information Systems Research, Vol.10, No.3, 255-275, 1999.

[17] Iivari, J., "From a macro innovation theory of IS diffusion to a micro innovation theory of IS adoption: An 
application to CASE adoption", in Avison, D., Kendall. J.E. and DeGross, J.I. (eds.), Human, Organizational and Social Dimensions of Information Systems Development, IFIP Transactions A-24, North-Holland, Amsterdam, 295-320, 1993.

[18] Lyytinen, K., and Goodman, S., "Finland: The unknown soldier on the IT front," Communications of the $A C M$, Vol.42, No.3, 13-17, 1999.

[19] Selz, D., and Klein, S., "Emerging electronic intermediaries - The case of the automotive industry," Pro ceedings of the 10th Bled Electronic Conference, Bled, Slovenia, 316-336, 1997.

[20] Kalakota, R. and Robinson, M., e-Business: Roadmap for Success, Reading, MA: Addison Wesley, 1999.

[21] Selz, D., and Klein, S., "The changing landscape of auto distribution," Institute of Electrical and Electronic Engineers, Vol.VI, 592-601, 1998.

[22] Foley, K., "Online and on the road," NUA Internet Surveys, (http://www.nua.ie/surveys/analysis/week.editorial/achives/2000/issuelnol16.html), March 6, 2000.

[23] Shetty, B., "Overhauling online car buying," Cambridge, MA: Forrester Research, Inc, 2000.

[24] Fletcher Research, "UK car buyers turning to the Internet," NUA Internet Surveys, (http://www.nua.ie/surveys/?f=VS\&art_id=905355251\&rel=true), 1999.

[25] Kalakota, R. and Robinson, M., e-Business: Roadmap for Success, Reading, MA: Addison Wesley, 1999.

[26] Marshall, P., Sor, R., and McKay, J., "The impacts of electronic commerce in the automobile industry: An empirical study in Western Australia," Proceedings of the Advanced Information Engineering 12th International Conference CAISE 2000, Stockholm, Sweden, 509-521, 2000.

[27] Selz, D., and Klein, S., "Emerging electronic intermediaries - The case of the automotive industry," Pro ceedings of the 10th Bled Electronic Conference, Bled, Slovenia, 316-336, 1997.

[28] Selz, D., and Klein, S., "The changing landscape of auto distribution," Institute of Electrical and Electronic Engineers, Vol.VI, 592-601, 1998.

[29] Selz, D., and Klein, S., "The changing landscape of auto distribution," Institute of Electrical and Electronic Engineers, Vol.VI, 592-601, 1998.

[30] Patton, M.Q., Qualitative Evaluation and Research methods, $2^{\text {nd }}$ edition, Newbury Park, CA: Sage Publi cations, 1990.

[31] Patton, M.Q., Qualitative Evaluation and Research methods, $2^{\text {nd }}$ edition, Newbury Park, CA: Sage Publications, 1990.

[32] Stake, R.E., The Art of Case Study Research, Thousand Oaks, CA: Sage Publications, 1995.

[33] Stake, R.E., The Art of Case Study Research, Thousand Oaks, CA: Sage Publications, 1995.

[34] Stake, R.E., The Art of Case Study Research, Thousand Oaks, CA: Sage Publications, 1995.

[35] Stake, R.E., The Art of Case Study Research, Thousand Oaks, CA: Sage Publications, 1995.

[36] Yin, R.K., Case Study Research, Design and Methods, 2n edition, Thousand Oaks, CA: Sage Publications, 1994.

[37] Patton, M.Q., Qualitative Evaluation and Research methods, $2^{\text {nd }}$ edition, Newbury Park, CA: Sage Publi cations, 1990.

[38] Lyytinen, K., and Goodman, S., "Finland: The unknown soldier on the IT front," Communications of the $A C M$, Vol.42, No.3, 13-17, 1999.

[39] Yin, R.K., Case Study Research, Design and Methods, 2n edition, Thousand Oaks, CA: Sage Publications, 1994.

[40] Klein, H., and Myers, M. D., "A set of principles for conducting and evaluating interpretive field studies in Information Systems," Management Information Systems Quarterly, Vol.23, No.1, 67-94, 1999.

[41] Lacity, M., and Janson, M., "Understanding qualitative data: A framework of text analysis methods," Journal of Management Information Systems, Vol.11, No.2, 137-155, 1994.

[42] Remenyi, D, and Williams, B, "The Nature of Research: Qualitative or Quantitative, Narrative or Paradig matic," Information Systems Journal, Vol.6, No.2, 131-146, 1996.

[43] Klein, H., and Myers, M. D., "A set of principles for conducting and evaluating interpretive field studies in Information Systems," Management Information Systems Quarterly, Vol.23, No.1, 67-94, 1999.

[44] Klein, H., and Myers, M. D., "A set of principles for conducting and evaluating interpretive field studies in Information Systems," Management Information Systems Quarterly, Vol.23, No.1, 67-94, 1999.

[45] Klein, H., and Myers, M. D., "A set of principles for conducting and evaluating interpretive field studies in Information Systems," Management Information Systems Quarterly, Vol.23, No.1, 67-94, 1999.

[46] Klein, H., and Myers, M. D., "A set of principles for conducting and evaluating interpretive field studies in Information Systems," Management Information Systems Quarterly, Vol.23, No.1, 67-94, 1999. 
[47] Klein, H., and Myers, M. D., "A set of principles for conducting and evaluating interpretive field studies in Information Systems," Management Information Systems Quarterly, Vol.23, No.1, 67-94, 1999.

[48] Klein, H., and Myers, M. D., "A set of principles for conducting and evaluating interpretive field studies in Information Systems," Management Information Systems Quarterly, Vol.23, No.1, 67-94, 1999.

[49] Klein, H., and Myers, M. D., "A set of principles for conducting and evaluating interpretive field studies in Information Systems," Management Information Systems Quarterly, Vol.23, No.1, 67-94, 1999.

[50] Klein, H., and Myers, M. D., "A set of principles for conducting and evaluating interpretive field studies in Information Systems," Management Information Systems Quarterly, Vol.23, No.1, 67-94, 1999.

[51] Walsham, G., "Interpretive Case Studies in Information Systems Research: Nature and Method," European Journal of Information Systems, Vol.4, No.2, 74-81, 1995.

[52] Klein, H., and Myers, M. D., "A set of principles for conducting and evaluating interpretive field studies in Information Systems," Management Information Systems Quarterly, Vol.23, No.1, 67-94, 1999.

[53] Selz, D., and Klein, S., "The changing landscape of auto distribution," Institute of Electrical and Electronic Engineers, Vol.VI, 592-601, 1998.

[54] Klein, H., and Myers, M. D., "A set of principles for conducting and evaluating interpretive field studies in Information Systems," Management Information Systems Quarterly, Vol.23, No.1, 67-94, 1999.

[55] Klein, H., and Myers, M. D., "A set of principles for conducting and evaluating interpretive field studies in Information Systems," Management Information Systems Quarterly, Vol.23, No.1, 67-94, 1999.

[56] Timmers, P., "Business models for electronic markets," Electronic Markets, Vol.8, No.2, 3-8, 1998.

[57] Grover, V., and Ramanlal, P., "Six Myths of Information Markets: Information Technology Networks, Electronic Commerce, and the Battle for Consumer Surplus," Management Information Systems Quarterly, Vol.23, No.4, 465-495, 1999.

[58] Rogers, E.M., Diffusion of Innovations, 4th edition, New York, NY: The Free Press, 1995.

[59] Swanson, E. B., "Information Systems Innovation Among Organizations," Management Science, Vol.40, No.9, 1069-1092, 1994.

[60] Rogers, E.M., Diffusion of Innovations, 4th edition, New York, NY: The Free Press, 1995.

[61] Swanson, E. B., "Information Systems Innovation Among Organizations," Management Science, Vol.40, No.9, 1069-1092, 1994.

[62] Rogers, E.M., Diffusion of Innovations, 4th edition, New York, NY: The Free Press, 1995.

[63] Nambisan, S. and Wang, Y. -M., "Web technology adoption and knowledge barriers," Journal of Organ izational Computing and Electronic Commerce, Vol. 10, No. 2, 129-147, 2000.

[64] Cohen, W.M. and Levinthal, D.A., "Absorptive capacity: A new perspective on learning and innovation", Administrative Science Quarterly, Vol. 35, No. 1, 128-152, 1990.

[65] Cohen, W.M. and Levinthal, D.A.,"Absorptive capacity: A new perspective on learning and innovation", Administrative Science Quarterly, Vol. 35, No. 1, 128-152, 1990.

[66] Cohen, W.M. and Levinthal, D.A.,"Absorptive capacity: A new perspective on learning and innovation”, Administrative Science Quarterly, Vol. 35, No. 1, 128-152, 1990.

[67] Cohen, W.M. and Levinthal, D.A., "Absorptive capacity: A new perspective on learning and innovation”, Administrative Science Quarterly, Vol. 35, No. 1, 128-152, 1990.

[68] Rogers, E.M., Diffusion of Innovations, 4th edition, New York, NY: The Free Press, 1995.

[69] Rogers, E.M., Diffusion of Innovations, 4th edition, New York, NY: The Free Press, 1995.

[70] Foss, N.J and Knudsen, C. (eds.), Towards a Competence Theory of the Firm, Routledge, London, 1996

[71] Zack, M. H., Knowledge Management and Strategy, Boston, MA: Butterworth Heinemann, 1996.

[72] Clemons, E.K. and Row, M.C., "Sustaining IT advantage: The role of structural differences", MIS Quar terly, Vol. 15, No. 3, 275-292, 1991.

[73] Mata, F.J., Fuerst, W.L. and Barney, J.B., "Information technology and sustained competitive advantage: A resource-based analysis", MIS Quarterly, Vol. 19, No. 4, 487-505, 1995.

[74] Jarvenpaa, S.L. and Leidner, D.E., "An information company in Mexico: Extending the resourcebased view of the firm to a developing country context", Information Systems Research, Vol. 9, No. 4, 342361, 1998.

[75] Bharadwaj, A.S., "A resource-based perspective on information technology capability and firm perfor mance: An empirical investigation", MIS Quarterly, Vol. 24, No. 1, 169-196, 2000.

[76] Peppard, J., Lambert, R. and Eswards, C., "Whose job is it anyway? Organizational information competencies for value creation", Information Systems Journal, Vol. 10, No. 4, 291-322, 2000.

[77] Hadjimanolis, A., "A resource-based view of innovativeness in small firms," Technology Analysis \& Strategic Management, Vol.12, No.2, 263-281, 2000. 
[78] Hadjimanolis, A., "A resource-based view of innovativeness in small firms," Technology Analysis \& Strategic Management, Vol.12, No.2, 263-281, 2000.

[79] Godfrey, P.C. and Gregersen, H.B., "Where do resources come from? A model of resource generation", Journal of High Technology Management Research, Vol.10, No.1, 1999.

[80] Godfrey, P.C. and Gregersen, H.B., "Where do resources come from? A model of resource generation", Journal of High Technology Management Research, Vol.10, No.1, 1999.

[81] Godfrey, P.C. and Gregersen, H.B., "Where do resources come from? A model of resource generation", Journal of High Technology Management Research, Vol.10, No.1, 1999.

[82] Barney, J., "Firm resources and sustained competitive advantage", Journal of Management, Vol. 17, No. 1, 99-120, 1991.

[83] Hall, R., "The strategic analysis of intangible resources," Strategic Management Journal, Vol.13, 135-144, 1992.

Hall, R. (1993) "A framework linking intangible resources and capabilities to sustainable competitive advantage," Strategic Management Journal, Vol.14, No.8, 607-618, 1993.

[84] Conner, K.R. and Prahalad, C.K., "A resource-based theory of the firm: Knowledge versus: Knowledge versus opportunism," Organization Science, Vol.7, No.5, 477-501, 1996.

[85] Grant, R.M., "Prospering in dynamically competitive environments: Organizational capability as knowl edge integration," Organization Science, Vol. 7, No. 4, 375-387, 1996.

[86] Teece, D.J., Piasono, G. and Shuen, A., "Dynamic capabilities and strategic management," Strategic Man agement Journal, Vol.18, No.7, 509-533, 1997.

[87] Mata, F.J., Fuerst, W.L. and Barney, J.B., "Information technology and sustained competitive advantage: A resource-based analysis", MIS Quarterly, Vol. 19, No. 4, 487-505, 1995.

[88] Grant, R.M., "The resource-based theory of competitive advantage; Implications for strategy formulation", California Management Review, Vol. 33, No. 3, 114-135, 1991.

[89] Amit, R. and Schoemaker, P.J.H., "Strategic assets and organizational rent", Strategic Management Jour nal, Vol. 14, 33-46, 1993.

[90] Grant, R.M., "Prospering in dynamically competitive environments: Organizational capability as knowl edge integration," Organization Science, Vol. 7, No. 4, 375-387, 1996.

[91] Teece, D.J., Piasono, G. and Shuen, A., "Dynamic capabilities and strategic management," Strategic Man agement Journal, Vol.18, No.7, 509-533, 1997.

[92] Jarvenpaa, S.L. and Leidner, D.E., "An information company in Mexico: Extending the resource-based view of the firm to a developing country context", Information Systems Research, Vol. 9, No. 4, 342-361, 1998.

[93] Bharadwaj, A.S., "A resource-based perspective on information technology capability and firm performance: An empirical investigation”, MIS Quarterly, Vol. 24, No. 1, 169-196, 2000.

[94] Priem, R.L. and Butler, J.E., "Is the resource-based "view" a useful perspective for strategic management research?" Academy of Management Review, Vol. 26, No. 1, 22-40, 2001.

[95] Barney, J., "Is the resource-based "view" a useful perspective for strategic management research? Yes", Academy of Management Review, Vol. 26, No. 1, 41-56, 2001.

[96] Grant, R.M., "Prospering in dynamically competitive environments: Organizational capability as knowl edge integration," Organization Science, Vol. 7, No. 4, 375-387, 1996.

[97] Teece, D.J., Piasono, G. and Shuen, A., "Dynamic capabilities and strategic management," Strategic Man agement Journal, Vol.18, No.7, 509-533, 1997.

[98] Grant, R.M., "Prospering in dynamically competitive environments: Organizational capability as knowl edge integration," Organization Science, Vol. 7, No. 4, 375-387, 1996.

[99] Teece, D.J., Piasono, G. and Shuen, A., "Dynamic capabilities and strategic management," Strategic Man agement Journal, Vol.18, No.7, 509-533, 1997.

[100] Teece, D.J., Piasono, G. and Shuen, A., "Dynamic capabilities and strategic management," Strategic Management Journal, Vol.18, No.7, 509-533, 1997.

[101] Cohen, W.M. and Levinthal, D.A. , "Absorptive capacity: A new perspective on learning and innovation", Administrative Science Quarterly, Vol. 35, No. 1, 128-152, 1990.

[102] Dierickx, I. and Cool, K., "Asset stock accumulation and sustainability of competitive advantage," Man agement Science, Vol. 35, No. 12, 1504-1511, 1989.

[103] Cohen, W.M. and Levinthal, D.A., "Absorptive capacity: A new perspective on learning and innovation", Administrative Science Quarterly, Vol. 35, No. 1, 128-152, 1990. 
[104] Applegate, L., Holsapple, C., Kalakota, R, Rademacher, F., and Whinston, A., "Electronic Commerce: Building Blocks of New Business Opportunities," Journal of Organizational Computing and Electronic Commerce, Vol.6, No.1, 1-11, 1996.

[105] Keen, P., and Ballance, C., On-line Profits: A Manager's Guide to Electronic Commerce, Boston, MA: Harvard Business Press, 1997.

[106] Selz, D., and Klein, S., "Emerging electronic intermediaries - The case of the automotive industry," Proceedings of the 10th Bled Electronic Conference, Bled, Slovenia, 316-336, 1997.

Selz, D., and Klein, S., "The changing landscape of auto distribution," Institute of Electrical and Electronic Engineers, Vol.VI, 592-601, 1998.

[107] Kalakota, R. and Robinson, M., e-Business: Roadmap for Success, Reading, MA: Addison Wesley, 1999.

[108] Miller, D. and Shamsie, J., "The resource-based view of the firm in two environments: The Hollywood film studios from 1936 to 1965," Academy of Management Journal, Vol. 39, No. 3, 519-543, 1996.

\section{APPENDIX}

\section{ECommerce interviewing guideline (adopters)}

1. How did the idea for a company website develop - was there someone in the company who pushed eCommerce? Do you start eCommerce as a new business strategy or in response to competitors? What are your expectations about customer response, organizational impact, and business results?

2. How much has your company invested in the eCommerce effort - are these investments for website development only or are there other expenses? Who designs and maintains the website? How much time does it take from eCommerce idea until website installation?

3. Is eCommerce compatible with your traditional way of doing business or, if not, how does eCommerce change the way business is done? Do you see any conflict between doing eCommerce business versus traditional business? What is the strategic role of eCommerce in your business?

4. How does eCommerce affect your business model, that is to say, advertising, marketing, customer contact, finding a car at the right price, purchasing the car, making payment, and car delivery?

5. New business initiatives demand changes in organizational structure, new relationships between management and company employees, and employee training. What organizational changes do you plan to make with eCommerce? Do employees need additional eCommerce related training?

6. What do you expect the customer reactions to be to the eCommerce initiative - will they be satisfied with the services provided, does it create new customers, increase customer loyalty, and increase car sales?

7. What are the things that need attention for eCommerce - things that just need to be absolutely correct for eCommerce to be successful? How did you identify these factors - before hand or after the fact?

8. Has your eCommerce strategy been successful - how do you measure or assess success? What are your future plans for eCommerce? What do you see as the major problems and risks of eCommerce in your business? 


\section{ECommerce interview guideline (non-adopters)}

1. The trade press often predicts that eCommerce will revolutionize commerce. It is suggested that consumers will buy almost everything through the Internet. On the other hand, there are people who think that the above predictors are over-optimistic. What is your own view about eCommerce and its development?

2. Have you considered transitioning to eCommerce and establishing your own website? If you have, when? How was the idea initiated? Was there somebody who especially pushed the idea?

3. Why did you end with the decision not to adopt eCommerce at this stage? Do you see any risks related with this decision?

4. How do you see the future of eCommerce in the automotive business? How may it affect advertising, marketing, customer contact, finding a car at the right price, purchasing the car, making payment, and car delivery?

5. Would you believe that a transition to eCommerce implies organizational changes? Would it have any impact on your management practices, changes in personnel, training of personnel, etc?

6. Are you acquainted with the eCommerce technology, computers, Internet and World Wide Web?

7. Have you estimated the economic investments required for the presence of your company on the Internet?

8. What are your future plans for eCommerce? What do you see as the major problems and risks of eCommerce in your business? 


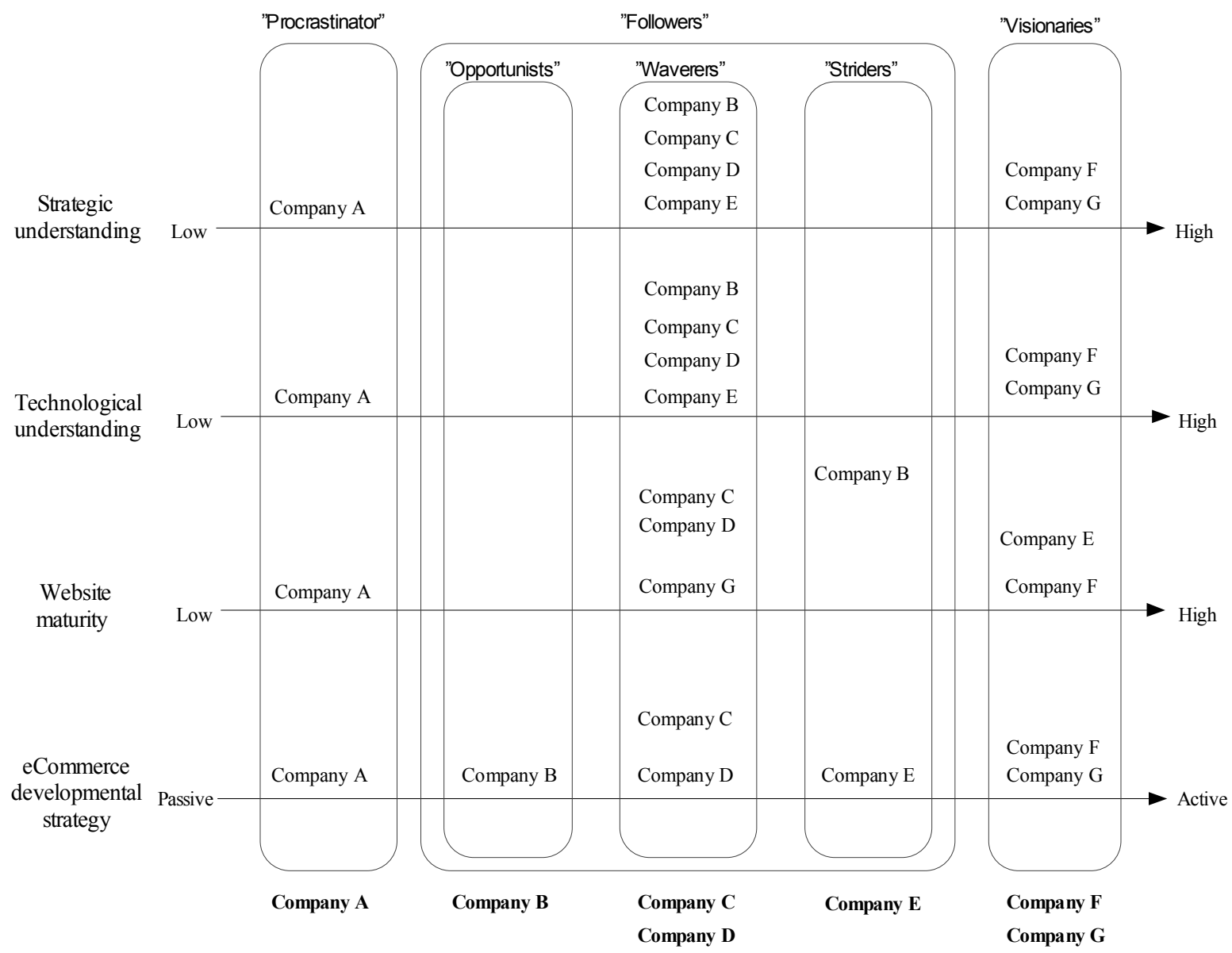

Figure 1: Emerging five adopter categories of eCommerce 
Figure 2: A conceptual model of factors affecting eCommerce adoption 
Table 1a Case Summaries

\begin{tabular}{|c|c|c|c|c|c|}
\hline Company & Company Background & Website & Website Initiator & Technology Base & $\begin{array}{c}\text { Remarks Concerning } \\
\text { eCommerce }\end{array}$ \\
\hline $\mathrm{A}$ & $\begin{array}{l}\text { Revenue: < Euro } 10 \text { (million) } \\
\text { New Cars: } 100 \text { to } 500 \\
\text { Used Cars: } 100 \text { to } 500 \\
\text { Personnel: }<20 \\
\text { Company Locations: } 1\end{array}$ & No Website & Not Applicable & $\begin{array}{l}\text { All salespersons use } \\
\text { computers daily for } \\
\text { preparing sales and } \\
\text { insurance documents. } \\
\text { Internet connection }\end{array}$ & $\begin{array}{l}\text { No specific future plans, } \\
\text { eCommerce adoption } \\
\text { likely within next five-year } \\
\text { period. }\end{array}$ \\
\hline $\mathrm{B}$ & $\begin{array}{l}\text { Revenue: Euro } 10 \text { (million) (est.) } \\
\text { New Cars: } 500 \text { to } 1000 \\
\text { Used Cars: } 1001 \text { to } 2000 \\
\text { Personnel: } 21 \text { to } 50 \\
\text { Company Locations: } 2\end{array}$ & $\begin{array}{l}\text { Implemented: } 2000 \\
\text { Investment: Euro } 0 \\
\text { New cars: Link to the importer's } \\
\text { website } \\
\text { Old cars: Link to an electronic } \\
\text { market place which gives a list of } \\
\text { used cars with links to details of } \\
\text { each car. } \\
\text { Personnel: Photos with contact } \\
\text { information }\end{array}$ & $\begin{array}{l}\text { Chief Executive Officer plus } \\
\text { two students from a local } \\
\text { educational institution. } \\
\text { Student project to satisfy } \\
\text { course requirements. }\end{array}$ & $\begin{array}{l}\text { All salespersons use } \\
\text { computers daily for } \\
\text { preparing sales and } \\
\text { insurance documents }\end{array}$ & $\begin{array}{l}\text { Website used to gain } \\
\text { eCommerce related } \\
\text { experience. No specific } \\
\text { future plans. }\end{array}$ \\
\hline $\mathrm{C}$ & $\begin{array}{l}\text { Revenue: Euro } 10 \text { to } 50 \text { (million) } \\
\text { New Cars: } 100 \text { to } 500 \text { (est.) } \\
\text { Used Cars: } 501 \text { to } 2000 \text { (est.) } \\
\text { Personnel: } 21 \text { to } 50 \\
\text { Company Locations: } 2\end{array}$ & $\begin{array}{l}\text { Implemented: } 1998 \\
\text { Investment: < Euro } 10000 \\
\text { New cars: Link to importers' } \\
\text { website. } \\
\text { Old cars: Simple list by location. }\end{array}$ & $\begin{array}{l}\text { Chief Executive Officer plus } \\
\text { one salesperson. }\end{array}$ & $\begin{array}{l}\text { All salespersons use } \\
\text { computers daily for } \\
\text { preparing sales and } \\
\text { insurance documents. }\end{array}$ & $\begin{array}{l}\text { Website used to gain } \\
\text { eCommerce related } \\
\text { experience. } \\
\text { Auto service bookings } \\
\text { using the Internet as a } \\
\text { future plan. }\end{array}$ \\
\hline $\mathrm{D}$ & $\begin{array}{l}\text { Revenue: < Euro } 10 \text { (million) } \\
\text { New Cars: } 100 \text { to } 500 \text { (est.) } \\
\text { Used Cars: } 100 \text { to } 500 \text { (est.) } \\
\text { Personnel: }<20 \\
\text { Company Locations: } 1\end{array}$ & $\begin{array}{l}\text { Implemented: } 1998 / 1999 \\
\text { Investment: < Euro } 2000 \\
\text { New cars: Link to importers' } \\
\text { website, when available. } \\
\text { Old cars: Simple list. }\end{array}$ & $\begin{array}{l}\text { Chief Executive Officer plus } \\
\text { sales manager. }\end{array}$ & $\begin{array}{l}\text { All salespersons use } \\
\text { computers daily for } \\
\text { preparing sales and } \\
\text { insurance documents. }\end{array}$ & $\begin{array}{l}\text { Website used to gain } \\
\text { eCommerce related } \\
\text { experience. } \\
\text { Future plans: Improve } \\
\text { website gradually. }\end{array}$ \\
\hline
\end{tabular}


Table 1b Case Summaries

\begin{tabular}{|c|c|c|c|c|c|}
\hline Company & Company Background & Website & Website Initiator & Technology Base & $\begin{array}{c}\text { Remarks Concerning } \\
\text { eCommerce }\end{array}$ \\
\hline $\mathrm{E}$ & $\begin{array}{l}\text { Revenue: Euro } 10 \text { to } 50 \text { (million) } \\
\text { New Cars: } 1000 \text { to } 2000 \\
\text { Used Cars: } 2001 \text { to } 3000 \\
\text { Personnel: } 51 \text { to } 100 \\
\text { Company Locations: } 5\end{array}$ & $\begin{array}{l}\text { Implemented: } 2000 . \\
\text { Investment: < Euro } 16000 \\
\text { New cars: Links to importers' web } \\
\text { pages } \\
\text { Old cars: A search engine; from } \\
\text { the result list links to details of } \\
\text { each car; integrated with } \\
\text { Automaster database } \\
\text { Service: Booking through internet } \\
\text { Personnel: Photos with brief intro- } \\
\text { ductions and photos }\end{array}$ & $\begin{array}{l}\text { Local Manager with support } \\
\text { from Chief Executive } \\
\text { Officer. }\end{array}$ & $\begin{array}{l}\text { All salespersons use } \\
\text { computers daily for } \\
\text { preparing sales and } \\
\text { insurance documents. } \\
\text { All five locations } \\
\text { networked by fixed lines }\end{array}$ & \\
\hline $\mathrm{F}$ & $\begin{array}{l}\text { Revenue: Euro } 50 \text { to } 100 \text { (million) } \\
\text { New Cars: } 1000 \text { to } 2000 \text { (est.) } \\
\text { Used Cars: } 2001 \text { to } 3000 \text { (est.) } \\
\text { Personnel: } 101 \text { to } 200 \\
\text { Company Locations: } 5\end{array}$ & $\begin{array}{l}\text { Implemented: } 1998 / 1999 \\
\text { Investment: < Euro } 35000 \\
\text { New cars: Link to an electronic } \\
\text { marketplace } \\
\text { Used cars: Link to an electronic } \\
\text { marketplace with a search engine } \\
\text { Service: Booking of time (pro- } \\
\text { posals) }\end{array}$ & $\begin{array}{l}\text { Liaison Manager (Direct } \\
\text { report of CEO, responsible } \\
\text { for special projects, for } \\
\text { coordination between } \\
\text { company departments and } \\
\text { between company and } \\
\text { outside organizations). }\end{array}$ & $\begin{array}{l}\text { All salespersons use } \\
\text { computers daily for } \\
\text { preparing sales and } \\
\text { insurance documents. } \\
\text { All locations networked } \\
\text { by fixed lines }\end{array}$ & $\begin{array}{l}\text { Planned investment for } \\
\text { further development } \\
13000-17000 \text { Euro } \\
\text { Developing extranets } \\
\text { specific to each company } \\
\text { customer }\end{array}$ \\
\hline G & $\begin{array}{l}\text { Revenue: Euro } 50 \text { to } 100 \text { (million) } \\
\text { New Cars: } 1000 \text { to } 2000 \text { (est.) } \\
\text { Used Cars: } 2001 \text { to } 3000 \text { (est.) } \\
\text { Personnel: } 101 \text { to } 200 \text { Company } \\
\text { Locations: } 5\end{array}$ & $\begin{array}{l}\text { Implemented: } 1995 / 1996 \\
\text { Investment: Not available } \\
\text { New cars: No links to importers' } \\
\text { websites } \\
\text { Old cars: A search engine; from } \\
\text { the result list links to details of } \\
\text { each car }\end{array}$ & & $\begin{array}{l}\text { All salespersons use } \\
\text { computers daily for } \\
\text { preparing sales and } \\
\text { insurance documents. } \\
\text { All locations networked } \\
\text { by fixed lines }\end{array}$ & $\begin{array}{l}\text { Service booking through } \\
\text { internet } \\
\text { Developing extranets } \\
\text { specific to each company } \\
\text { customer } \\
\text { Application of the mobile } \\
\text { phone technology so that, } \\
\text { for example, when service } \\
\text { is complete the system } \\
\text { sends automatically a short } \\
\text { message to the customer's } \\
\text { mobile phone that the car } \\
\text { is ready }\end{array}$ \\
\hline
\end{tabular}


